\title{
Analisis Keragaman Genetik Dyera costulata (Miq) Hook.f. Berdasarkan Marka "Random Amplified Polymorphic DNA"
}

\author{
Genetic Variation Analysis of Dyera costulata (Miq) Hook.f. Based on Random Amplified \\ Polymorphic DNA
}

\author{
Yuyu Suryasari Poerba* dan Elizabeth A. Widjaya \\ Bidang Botani, Pusat Penelitian Biologi LIPI \\ Jl. Raya Bogor Km 46.5 Cibinong, Bogor \\ E-mail: yyspoerba@yahoo.com *Penulis untuk korespondensi
}

\begin{abstract}
Dyera costulata (Miq.) Hook.f (Apocynaceae) is a large tree of the lowland tropical rain forest of Southeast Asia that occurs in Thailand, the Malay Peninsula and on the islands of Sumatera and Borneo. Its economic value was in its latex, used as gum chile in the manifacture of chewing gum. Nowadays the timber of this species is largely utilized for the manufacture of pencils and picture frames. The information on genetic diversity of the species is very limited. Hence studies were initiated and genetic diversity were estimated using Random Amplified Polymorphic (RAPD) markers in 47 accessions of Dyera costulata procured from different geographical regions of Jambi. Four selected Operon primers $(10$ mer) generated a total of 90 consistent amplification products ranging from $150 \mathrm{bp}$ to $2.8 \mathrm{~Kb}$. The cluster analysis showed that the 47 individuals were separated into one main cluster and one individual. The range of genetic dissimilarity value among samples was from 0.06 to 0.71 , while genetic distance among populations was from 0.17 to 0.42 . These values showed that those 47 accessions of $D$. costulata from Jambi was genetically originated from diverse population.
\end{abstract}

Key words: Dyera costulata, genetic variation, RAPD

\begin{abstract}
Abstrak
Dyera costulata (Miq.) Hook.f (Apocynaceae) adalah jenis pohon besar hutan hujan tropis dataran rendah Asia Tenggara, yang tumbuh di Thailand, Semenanjung Malaysia, dan di pulau Sumatera dan Borneo. Nilai ekonomis pohon ini adalah getahnya, yang digunakan sebagai gum chile dalam pembuatan permen karet. Akhir-akhir ini, kayu pohon jenis ini digunakan dalam pembuatan pensil dan bingkai foto. Informasi keragaman genetik jenis pohon ini sangat terbatas. Oleh karena itu penelitian ini dilakukan, dan keragaman genetik diduga dengan menggunakan marka Random Amplified Polymorphic (RAPD) pada 47 aksesi Dyera costulata yang berasal dari berbegai daerah di Jambi. Empat primer terpilih dari Operon (10 mer) menghasilkan 90 produk amplifikasi yang konsisten yang ukurannya berkisar dari 150 bp hingga Kb. Analisis kluster menunjukkan bahwa ke-47 individu terkelompok ke dalam satu kluster dan satu individu terpisah sendiri. Nilai ketidaksamaan genetik berkisar dari 0,17 hingga 0,42. Hasil ini menunjukkan bahwa ke-47 aksesi $D$. costulata dari Jambi berasal dari populasi yang beragam.
\end{abstract}

Kata kunci: Dyera costulata, keragaman genetik, RAPD

Diterima: 11 Mei 2009, disetujui: 08 Desember 2009

\section{Pendahuluan}

Dyera costulata (Miq.) Hook.f (Apocynaceae), di Indonesia dikenal dengan Jelutung tersebar di Sumatra dan Kalimantan, dan pulau-pulau di antaranya. Kayu jelutung ringan dan lunak, mudah dibentuk dan stabil. Biasanya digunakan sebagai bahan untuk papan gambar, mainan (toys), pensil, bingkai foto, korek api dan bagian-bagian furnitur, termasuk untuk lis kayu hiasan dinding, produksi veneer dan plywood (kayu lapis). Lateksnya digunakan 
untuk pembuatan permen karet (chewing gum), sehingga species tersebut termasuk pohon serbaguna. Di Malaysia D.costulata menjadi salah satu komoditi ekspor (Norwati, 2002; Soerianegara dan Lemmens, 1993; Boer dan Ella, 2000). Di Indonesia, walaupun pohon Jelutung sudah dimanfaatkan dan dieksploitasi sejak lama, upaya rehabilitasi dan konservasinya serta penebangan liar yang masih marak dilakukan (Anonimous, 2006), sehingga keberadaan pohon jelutung semakin terancam (Hardiyanto dan Na'iem, 2001). Pohon Jelutung sebenarnya termasuk pohon yang dilindungi di bawah SK Mentan No. 54/Kpts/ Um/2/1972, dalam SK tersebut ada larangan penebangan pohon berdiameter di bawah $50 \mathrm{~cm}$ (Wiriadinata, 2001).

Pemeliharaan keragaman genetik perlu untuk keberadaan/survival suatu spesies dalam jangka panjang karena keragaman genetik menyediakan potensi berevolusinya tumbuhan tersebut. Menurunnya keragaman genetik akibat kehilangan alel-alel tertentu menurunkan kemampuan populasi tumbuhan untuk merespon perubahan lingkungan biotik (misalnya patogen) dan abiotik (Pither et al., 2003). Hal-hal tersebut menjadikan penentuan keragaman genetik suatu species menjadi penting.

Jelutung belum banyak diketahui variasi genetiknya (Norwati, 2002), dan studi genetik serta populasi jelutung belum banyak dilaporkan. Penelitian ini bertujuan mengidentifikasi variasi genetik $D$. costulata dari empat lokasi di Jambi yang digunakan dalam perbanyakan tanaman dalam program domestikasi D.costulata, berdasarkan marka random amplified polymorhic DNA (RAPD). Marka RAPD digunakan dalam penelitian ini karena selain relatif mudah dan cost effective, marka ini sudah banyak digunakan untuk mengidentifikasi variasi genetik jenis-jenis pohon kayu tropis lainnya, misal Trichilia pallid (Meliacecae) (Mori et al., 2004); Terminalia amazona (Pither et al., 2003); Dipterocarpaceae (Rath et al., 1998), Melia volkensii (Runo et al., 2004); Azadirachta indica (Singhetal)., 2005) dan Shorea laevis (Siregar et al., 1998) RAPD memiliki kelemahan dalam konsistensi produk amplifikasi (Jones et al.,1997), hal ini dapat diatasi dengan mengoptimalkan ekstraksi, dan kondisi PCR serta pemilihan primer yang tepat.

\section{Metode Penelitian}

Bahan yang digunakan adalah 47 aksesi D.costulata yang berasal dari daerah Jambi dan koleksi Pusat Penelitian Tanaman Karet, Medan. Bahan penelitian identifikasi genetik terdiri atas empat populasi, yaitu: (1) Sungai Batang Hari (DHL), Jambi (2) Teluk Pulai, Palembang, (3) TN Berbak, Jambi, dan (4) Koleksi Pusat Penelitian Karet, Medan dengan tiap-tiap populasi terdiri atas 9-14 individu (duplikasi). Material DNA ke-47 aksesi ini berupa potongan daun muda yang dikeringkan dengan silica gel, sesuai pedoman pengambilan sampel untuk material DNA (Widjaja dan Poerba, 2004).

\section{Ekstraksi dan Isolasi DNA}

Ekstraksi DNA dilakukan dengan menggunakan metode CTAB yang dimodifikasi (Delaporta et al., 1983), yaitu penambahan RNase dengan konsentrasi akhir DNA 250 $\mu \mathrm{g} / \mathrm{mL}$. Kuantitas setiap DNA hasil isolasi diukur dengan Flourometer (Shimadzu UV1201), sedangkan kualitasnya dilihat pada gel $0.8 \%$ hasil elektroforesis. Ekstraksi DNA yang menghasilkan kuantitas dan kualitas DNA yang cukup baik, dilanjutkan amplifikasi dengan metode PCR (Polymerase Chain Reaction).

\section{Amplifikasi DNA}

Amplifikasi DNA dilakukan berdasarkan metode Williams et al., (1990) dimodifikasi menggunakan empat primer RAPD terpilih, yaitu OPU-06, OPU-07, OPN-14 dan OPN-19 (Operon Technology Ltd) (Tabel 1), yang merupakan primer polimorfik dan sebelumnya diuji pada jelutung (Poerba dan Widjaya, tidak diterbitkan). PCR dilakukan pada total volume $15 \mu$. Tiap-tiap tabung PCR berisi $0.2 \mathrm{nM}$ dNTPs; $1.5 \mu \mathrm{l}$ bufer reaksi; $2 \mathrm{mM} \mathrm{MgCl}_{2} ; 10 \mathrm{ng}$ DNA; 5 pmol primer tunggal; dan 1 unit Taq DNA polymerase (Promega).

Reaksi PCR dilakukan menggunakan thermocycler (Takara). Pra-PCR pada suhu $94^{\circ} \mathrm{C}$ selama 5 menit, kemudian diikuti oleh 45 siklus yang terdiri denaturasi 1 menit pada suhu $94^{\circ} \mathrm{C}$, penempelan primer 1 menit pada suhu $36^{\circ} \mathrm{C}$, dan 2 menit pemanjangan pada suhu $72^{\circ} \mathrm{C}$. Setelah 45 siklus selesai, kemudian diikuti pascaPCR 4 menit pada suhu $72^{\circ} \mathrm{C}$ dan pendinginan pada suhu $4^{\circ} \mathrm{C}$ selama 30 menit. Hasil amplifikasi 
difraksinasi secara elektroforesis menggunakan Mupid Mini Cell pada gel agarosa 2.0\% dalam bufer TEA (Tris-EDTA) selama 60 menit pada $50 \mathrm{~V}$, kemudian gel direndam dalam larutan ethidium bromida dengan konsentrasi akhir $1 \mu \mathrm{g}$ $\mathrm{ml}^{-1}$ selama 10 menit. Hasil pemisahan fragmen DNA dideteksi dan difoto menggunakan Gel Documentation System. Sebagai standar digunakan 100 bp DNA ladder (Promega) untuk menetapkan ukuran pita hasil amplifikasi DNA.

\section{Analisis Data}

Setiap pita RAPD dianggap sebagai satu alel putatif. Hanya alel yang menunjukkan pita yang jelas yang digunakan untuk skoring: ada (1) dan kosong (0). Matriks binarifenotip RAPD ini kemudian disusun untuk digunakan pada analisis kluster dengan menggunakan UPGMA program NTSYS-pc versi 1.80 (Rohlf, 1993). Nilai kesamaan genetika diambil dari Simple Matching Coefficient (Dunn dan Everitt, 1982; Rohlf, 1993), sedangkan nilai ketidaksamaan genetik merupakan pengurangan nilai matrix of simmilarity oleh 1 (Dunn dan Everitt, 1982). Matrik jarak genetik antar populasi dihitung dengan menggunakan Nei's unbiased genetic distances (Nei, 1978) dengan program POPGENE software (Yeh et al., 1999). Dendrogram yang dihasilkan dari analisis dilihat menggunakan program TREEVIEW software (Page, 1998).

\section{Hasil dan Pembahasan}

\section{Analisis Profil RAPD}

Hasil amplifikasi total genom DNA dengan menggunakan empat primer RAPD (OPN-14, OPN-19, OPU-06, dan OPU-07 dari Operon Technology), pada 47 aksesi jelutung menghasilkan produk PCR yang dapat dibaca dan diskor, sehingga hasilnya dapat dianalisis. Sekuens dari keempat primer ini dan jumlah marka RAPD yang dihasilkan tertera pada Tabel 1. Hasil PCR dengan satu primer (OPU-06) dapat dilihat pada Gambar 1. Hasil pengamatan menunjukkan bahwa diperoleh 60 fragmen DNA yang berukuran dari 200 bp hingga $3.0 \mathrm{~kb}$, 93,33\% di antaranya merupakan fragmen DNA polimorfik (Tabel 1). Keempat primer menghasilkan 14-16 fragmen DNA yang dapat dideteksi dan diskor. Hal ini menunjukkan marka RAPD yang digunakan memiliki tingkat polimorfisme yang tinggi $(>50 \%$ pita polimorfik). Rata-rata setiap primer menghasilkan 15 pita yang dapat dideteksi dan diskor. Jumlah maksimum pita polimorfik yaitu 16 terdapat pada primer OPN-19 (Tabel 1).

Jumlah dan intensitas pita DNA yang dihasilkan setelah amplifikasi DNA dengan PCR sangat tergantung kemampuan primer mengenal urutan DNA komplementernya pada cetakan DNA (DNA template) yang digunakan (Tingey et al., 1994). Hasil amplifikasi DNA $D$. costulata menggunakan empat primer acak diatas tidak selalu memperoleh pita dengan intensitas yang sama. Intensitas pita DNA hasil amplifikasi pada setiap primer dipengaruhi oleh kemurnian dan konsentrasi cetakan DNA. Cetakan DNA yang mengandung senyawasenyawa seperti polisakarida dan senyawa fenolik, serta konsentrasi DNA cetakan yang terlalu kecil sering menghasilkan pita DNA amplifikasi yang redup atau tidak jelas (Weeden et al., 1992). Selain itu, sebaran situs penempelan primer pada cetakan DNA dan adanya kompetisi tempat penempelan primer pada cetakan DNA dapat menyebabkan satu fragmen diamplifikasi dalam jumlah banyak dan fragmen lainnya sedikit. Proses amplifikasi mungkin saja diinisiasi pada beberapa tempat, tetapi hanya beberapa set yang dapat dideteksi sebagai pita sesudah diamplifikasi (Weeden et al., 1992).

Pemilihan primer pada analisis RAPD berpengaruh terhadap polimorfisme pita yang dihasilkan, karena setiap primer memiliki situs penempelan tersendiri. Akibatnya, pita DNA polimorfik yang dihasilkan setiap primer menjadi berbeda, baik dalam ukuran banyaknya pasang basa maupun jumlah pita DNA.

\section{Analisis Kluster Antar Individu dan Antar Populasi}

Analisis kluster kesamaan genetik pada 47 sampel D. costulata menunjukkan pemisahan sampel ke dalam kluster-kluster yang mengelompok berdasarkan populasinya, sebagian secara acak (Gambar 2). Dendrogram menunjukkan dua kluster utama (A; koefisien kesamaan 0,61), dan kluster B (koefisien kesamaan 0,50). Kluster A merupakan kelompok 
yang berasal dari satu populasi (populasi 2). Kluster B terdiri dari kelompok C yang berasal dari satu populasi, dan D yang terdiri dari subkelompok yang sebagian besar dari populasi yang sama (E dan F), dan mengelompok secara acak (G). Fenomena yang menarik dari hasil analisis kluster ini adalah mengelompoknya individu dari populasi yang berlainan ke dalam satu kluster. Hal ini mengindikasikan adanya keragaman genetik pada $D$. costulata, yang disebabkan oleh adanya rekombinasi genetik. Hal ini menunjukkan adanya penyerbukan silang pada $D$. costulata yang cukup tinggi.

Nilai ketidaksamaan genetik untuk ke-47 sampel berkisar dari $0,06-0,71$, yang tertinggi $(0,71)$ terdapat antara sampel 4 (TN Berbak, Jambi) dan 23 (populasi Hutan Produksi PT DHL) dan paling rendah $(0,06)$ antara sampel 37 dan 38 (keduanya termasuk dalam populasi Koleksi Pusat Penelitian Karet, Medan). Hal ini menunjukkan adanya keragaman genetik antarindividu dan antarpopulasi. Pendugaan pertama adalah lokus polimorfik yang digunakan dalam analisis ini sudah dipilih yang memiliki polimorfisme yang tinggi. Selain itu, telah terjadi rekombinasi genetik yang mungkin terjadi dan telah terjadi rekombinasi random dalam sampel akibat terjadinya outcrossing yang memang sangat umum terjadi pada jenis-jenis tumbuhan berbunga dengan penyerbukan silang sehingga menyebabkan tingginya keragaman antarindividu. Hal yang sama juga terdapat pada tumbuhan tropis yang memperlihatkan keragaman genetik yang tinggi, seperti Terminalia amazona (Pither et al., 2003) dan Eugenia dysenterica (Telles et al., 2003) dan kebanyakan terjadi dalam populasi (Pither et al., 2003; Telles et al., 2003). Hal ini menimbulkan dugaan bahwa tumbuhan ini menyerbuk silang. Kondisi yang ini sama juga ditunjukkan dengan penampilan morfologi tumbuhan jelutung. Warna daun dan batang serta morfologi daun menunjukkan perbedaan. Daun ada yang berwarna kemerahan, hijau tua, dan hijau muda, sedangkan batang ada berwarna coklat gelap dan coklat kehijauan. Demikian juga dengan kanopi, ada yang mengerucut dan ada yang melebar.

Fenomena yang menarik adalah tiga individu $(6,9,11)$ terpisah dari populasinya (1). Ketiga nomor ini memiliki karakter morfologi yang berbeda. Nomor 11 memiliki warna pucuk daun yang merah, sehingga disebut jelutung merah, yang secara genetik terpisah dari seluruh populasi 1, sedangkan kedua individu lainnya yaitu no 6 dan no 9, yang keduanya merupakan jelutung hitam, yang memiliki warna batang hijau tua sampai kehitaman terpisah dari populasi no 1 .

Keragaman genetika yang terjadi dalam populasi ini mengindikasikan bahwa ada perbedaan properti genetik dari setiap pohon induk jelutung, seperti pada penampilan fenotifiknya. Keragaman genetik antarindividu pada tiap populasi dapat dilihat pada Tabel 2 . Populasi 1 (TN Berbak Jambi) memiliki nilai na $(1,8333 \pm 0,3758)$, ne $(1,5969 \pm 0,3735)$, dan $\mathrm{He}$ $(0,3008 \pm 0,1867)$ tertinggi dibandingkan dengan populasi lainnya. Populasi 2 (Koleksi Kehutanan asal Teluk Pulai, Palembang) menunjukkan nilai keragaman genetik yang paling rendah dengan nilai rata-rata $n a=1,3500 \pm 0,4810, n e=$ $1,1984 \pm 0,3352, \quad$ PLP $=35 \%$ dan $\mathrm{H}_{\mathrm{e}}=$ $0,1161 \pm 0,1814$. Hal ini mengindikasikan bahwa daerah populasi 1 (TN Berbak, Jambi) merupakan salah satu pusat keragaman $D$. costulata di Jambi. Namun, analisis lebih mendalam diperlukan dengan menggunakan aksesi dari populasi lain dan primer yang lebih banyak untuk membuktikan hasil ini.

Tabel 1. Primer yang digunakan dan jumlah pita DNA hasil amplifikasi pada 47 sampel Dyera costulata.

\begin{tabular}{cccc}
\hline \hline Kode Primer & Urutan Basa 5'-3' & Jumlah Fragmen & Jumlah Fragmen Polimorfik \\
\hline \hline OPN-14 & TCGTGCGGG & 15 & $14(93,33 \%)$ \\
OPN-19 & GTCCGTACT & 16 & $16(100 \%)$ \\
OPU-06 & ACCTTTGCG & 15 & $13(86,67 \%)$ \\
OPU-07 & CCTGCTCAT & 14 & $13(2,86 \%)$ \\
\hline \hline & Jumlah & $\mathbf{6 0}$ & $\mathbf{5 6 ( 9 3 , 3 3 \% )}$ \\
Rata-rata & $\mathbf{1 5}$ & $\mathbf{1 4}$ \\
\hline \hline
\end{tabular}




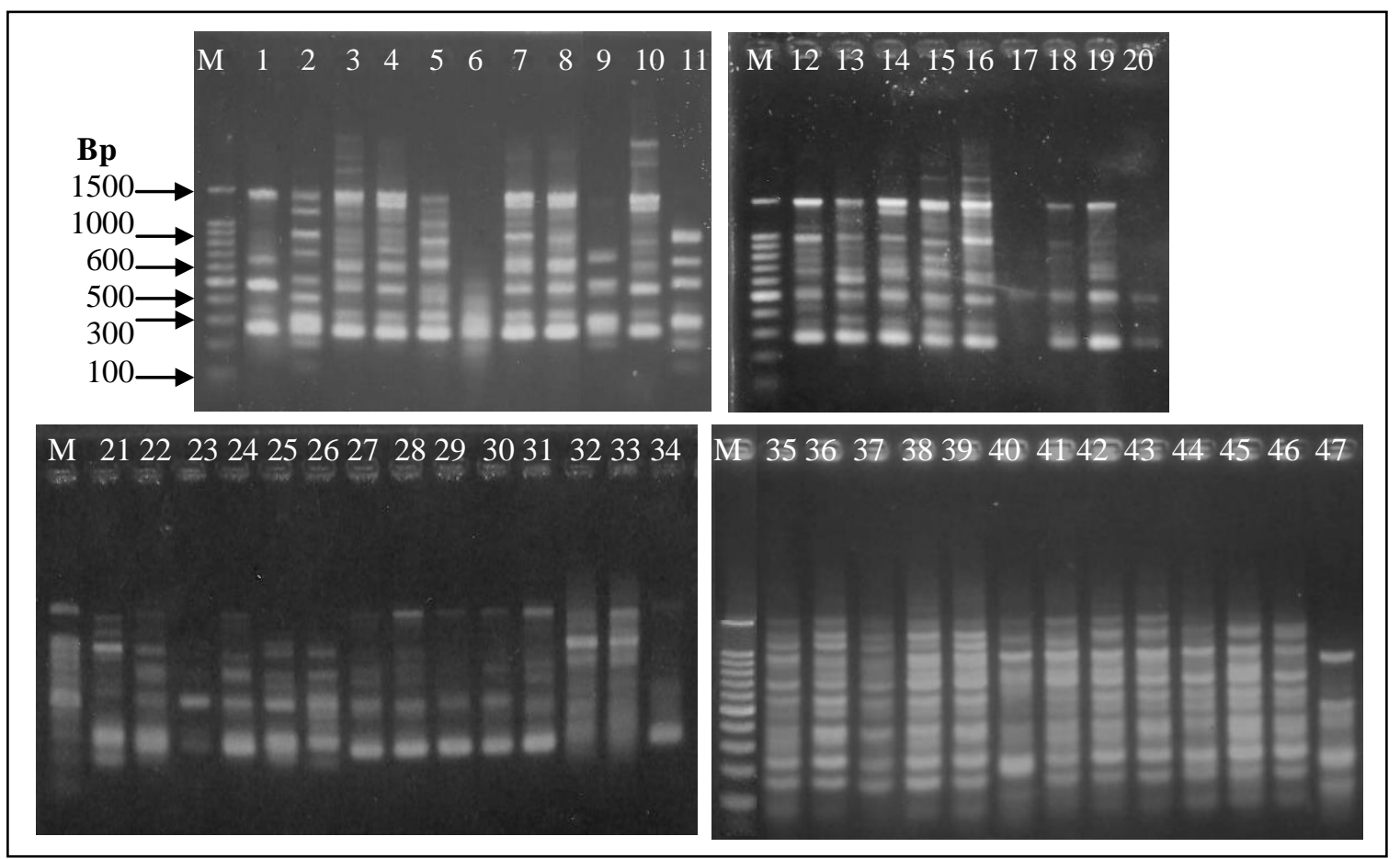

Gambar 1. Pola pita RAPD pada 47 sampel Dyera costulata dengan primer OPU-06.

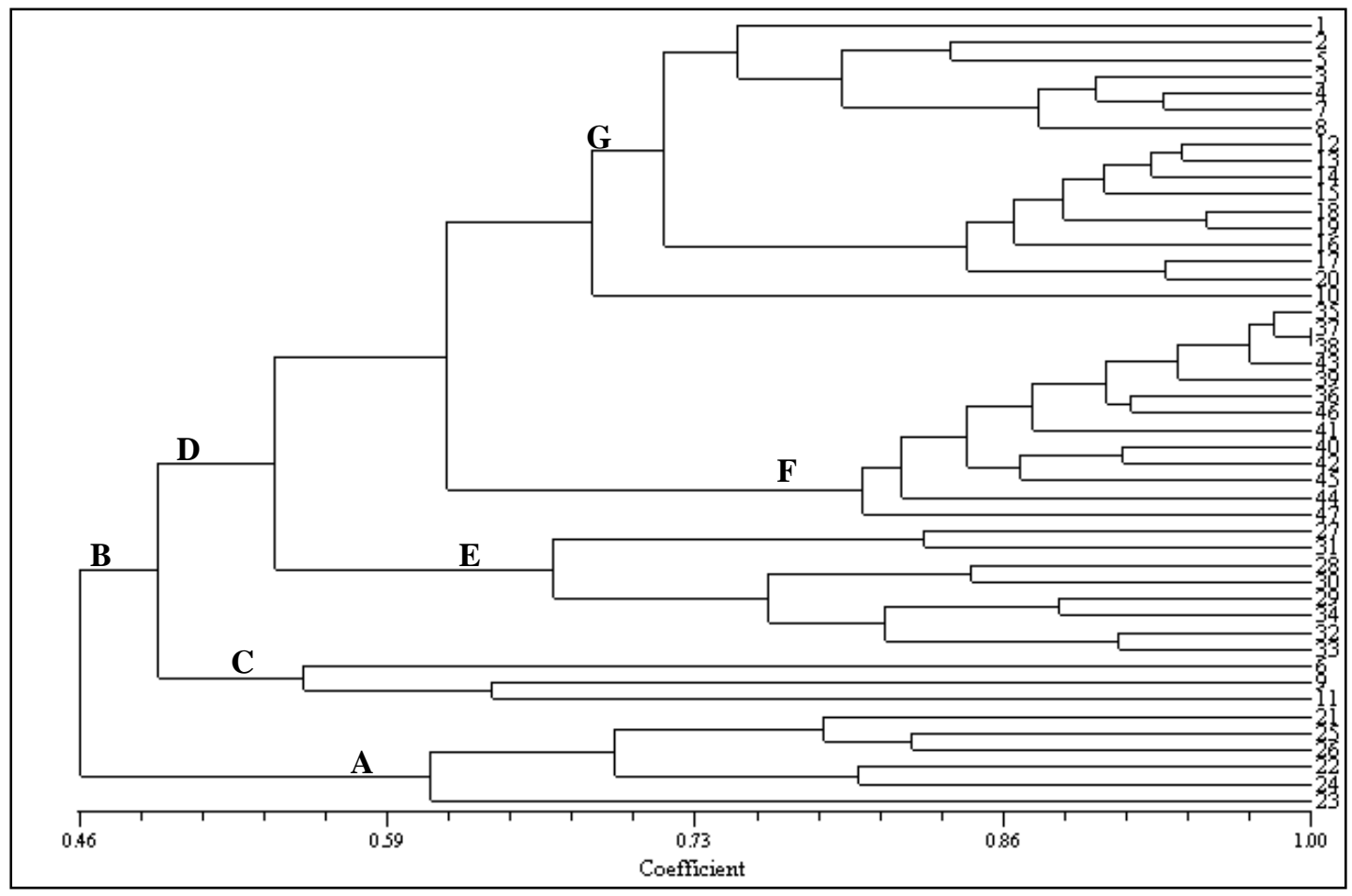

Gambar 2. Dendrogram 47 sampel Dyera costulata

Keterangan: $1-11=$ TN Berbak, Jambi, Kelompok Sungai Batang hari, Kab. Muaro Jambi, 12-20 = Koleksi Kehutanan asal Teluk Pulai, Palembang, 21-34= Hutan Produksi PT DHL, dan 35-47 = Koleksi Pusat Penelitian Karet, Medan. Dendrogram dibuat berdasarkan UPGMA (unweighted pair group with arithmeatic average) program NTSYS-pc (numerical taxonomy system) versi 2.0 (Rohlf, 1993). Nilai kesamaan genetika diambil dari Simple Matching Coefficient (Dunn dan Everitt, 1982; Rohlf, 1993). 
Hasil penelitian ini juga mengindikasikan adanya penerbukan silang yang tinggi dalam jenis ini yang memelihara keragaman genetik melalui reproduksi seksual. Adapun Populasi 2 (Koleksi Kehutanan asal Teluk Pulai, Palembang) merupakan populasi yang memiliki keragaman genetik yang paling rendah. Selain itu, juga mengindikasikan bahwa populasi berasal dari induk yang terbatas atau sama. sama atau tidak banyak.

Selanjutnya untuk mengetahui sebaran fenotip RAPD antarpopulasi, dibuat cladogram pengelompokkan berdasarkan jarak genetik (Nei, 1978) (Gambar 3). Cladogram yang dibuat dengan metode UPGMA (Unweighted Pair Group Method with Arithmetic mean) menunjukkan hubungan kekerabatan genetik antara populasi yang dianalisis berdasarkan matrik Nei's genetic distance di antara populasi (Tabel 3). Secara umum, populasi D. costulata membentuk dua kelompok. Kelompok pertama, terdiri atas populasi 2, kelompok kedua terdiri atas populasi 1, 3 dan 4 yang mengelompok menjadi satu yang menunjukkan kesamaan properti genetik.

Nilai jarak genetik di antara populasi berkisar 0,1690-0,4187. Jarak genetik tertinggi (0.4187) terdapat antara populasi 2 (Koleksi
Kehutanan asal Teluk Pulai, Palembang) dan 3 (Hutan Produksi PT DHL), sedangkan jarak genetik terdekat $(0,1690)$ terdapat antara antara populasi 1 (TN Berbak, Jambi) dan 3 (Hutan Produksi PT DHL), yang menunjukkan bahwa populasi 2 (TN Berbak, Jambi) dan 3 (Hutan Produksi PT DHL), memiliki properti genetik yang mirip, kemungkinan kedua populasi berasal dari sumber yang sama.

Hasil penelitian ini menunjukkan bahwa nilai ketidaksamaan genetik antarindividu $(0,06-0,71)$ pada jelutung lebih tinggi daripada nilai jarak genetik antarpopulasi $(0,17-0,42)$. Hal yang sama juga terdapat pada tumbuhan tropis lain yang memperlihatkan keragaman genetik yang tinggi, dan kebanyakan terjadi dalam populasi (Islam et al., 2005; Pither et al., 2003; Telles et al., 2003), khususnya dalam cendana (Shashidhara et al., 2003; Rimbawanto et al., 2006).

Upaya konservasi pembudidayan dan pemuliaan $D$. costulata hendaknya didasarkan atas kondisi properti genetika setiap populasi dan individu dalam setiap populasi, khususnya populasi 1 yang memiliki keragaman genetik tertinggi di Jambi perlu mendapat perhatian dalam pelestariannya.

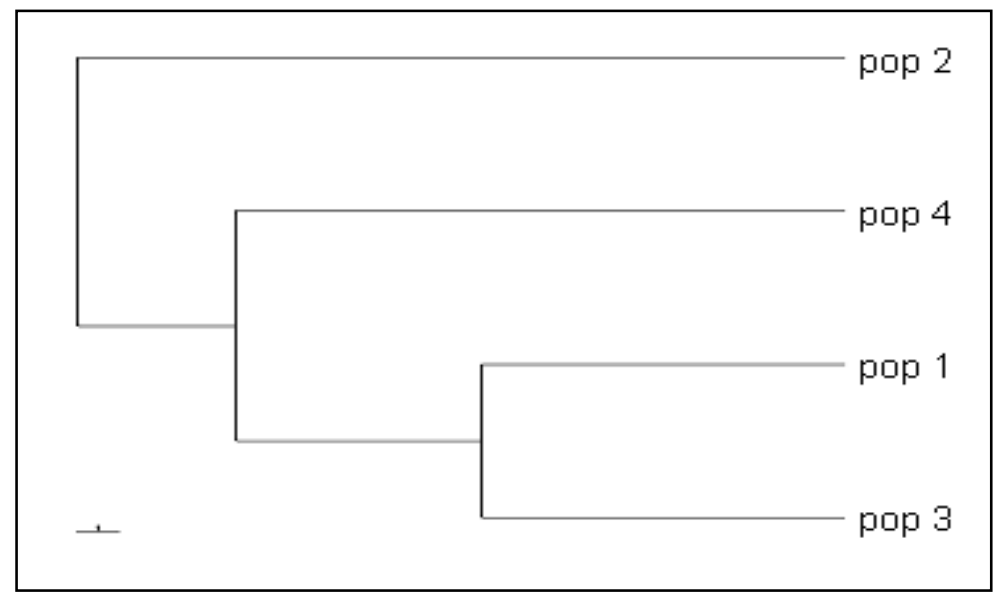

Gambar 3. Dendogram enam populasi Dyera costulata Miq.

Keterangan: Populasi $1=$ TN Berbak, Jambi, Kelompok Sungai Batang hari, Kab. Muaro Jambi, Populasi 2 = Koleksi Kehutanan asal Teluk Pulai, Palembang, Populasi 3= Hutan Produksi PT DHL, dan Populasi 4= Koleksi Pusat Penelitian Karet, Medan. Dendrogram dibuat berdasarkan Nei's (1972) Genetic distance: Method = UPGMA (Modifikasi dari NEIGHBOR procedure of PHYLIP Version 3.50) (dari Yeh et al., 1999). 
Tabel 2. Keragaman genetik antarindividu pada tiap populasi.

\begin{tabular}{|c|c|c|c|c|c|c|}
\hline Populasi & $\begin{array}{l}\text { Ukuran } \\
\text { Sampel } \\
\end{array}$ & $\mathbf{N a}$ & $\mathrm{Ne}$ & $\begin{array}{c}\text { Jmlh Lokus } \\
\text { Polimorfik } \\
\end{array}$ & $\begin{array}{c}\text { Persen Lokus } \\
\text { Polimorfik } \\
\end{array}$ & $\mathbf{H e}$ \\
\hline$\overline{11}$ & 11 & $1,8333 \pm 0,3758$ & $1,1,5969 \pm 0,3735$ & $\overline{50}$ & $83,33 \%$ & $\overline{0,3008 \pm 0,18670,4457 \pm 0,2540}$ \\
\hline 2 & 9 & $1,3500 \pm 0,4810$ & $1,1984 \pm 0,3352$ & 21 & $35,00 \%$ & $0,1161 \pm 0,18140,1754 \pm 0,2620$ \\
\hline 3 & 14 & $1,5833+0,4972$ & $1,3535+0,3729$ & 35 & $58,33 \%$ & $0,2076+0,20070,3103+0,2879$ \\
\hline 4 & 13 & $1,4333 \pm 0,4997$ & $1,2344 \pm 0,3297$ & 26 & $43,33 \%$ & $0,1418 \pm 0,16490,2158 \pm 0,2698$ \\
\hline Total & 47 & & & & & \\
\hline
\end{tabular}

Tabel 3. Nilai genetic distance (Nei, 1978) pada empat populasi Dyera costulata (Miq) Hook.f.

\begin{tabular}{ccccc}
\hline \hline Populasi & $\mathbf{1}$ & $\mathbf{2}$ & $\mathbf{3}$ & $\mathbf{4}$ \\
\hline \hline 1 & $* * *$ & & & \\
2 & 0,2711 & $* * *$ & $* * *$ & \\
3 & 0,1690 & 0,4187 & 0,2583 & $* * *$ \\
\hline
\end{tabular}

\section{Kesimpulan dan Saran}

\section{Kesimpulan}

Keragaman genetik 47 koleksi Dyera costulata dapat dideteksi dengan menggunakan marka RAPD. Dari empat primer RAPD diperoleh 60 pita DNA, 93,33\% di antaranya merupakan pita polimorfik. Dendrogram hasil analisis kluster menunjukkan terdapat dua kluster, yang besar mengelompok berdasarkan populasinya. Nilai ketidaksamaan genetik antar individu jelutung berkisar antara 0,06-0,71, dengan yang tertinggi $(0,71)$ terdapat antara sampel 4 dan 23 dan paling rendah $(0,06)$ antara sampel 37 dan 38 . Nilai jarak genetik antar populasi pada jelutung jauh lebih rendah yaitu 0,17 s.d. 0,42. Penelitian ini menunjukkan bahwa nilai ketidaksamaan genetik antarindividu pada jelutung lebih tinggi daripada nilai ketidaksamaan genetik antarpopulasi.

\section{Saran}

Dari hasil penelitian ini menunjukkan bahwa perlu dilakukan penelitian lanjutan untuk memperoleh gambaran yang lebih menyeluruh mengenai kondisi keragaman genetika jelutung di berbagai populasi yang ada di Jambi dan daerah konservasi lainnya dengan menggunakan lebih banyak primer RAPD dan/atau dengan menggunakan marka molekuler selain RAPD untuk mendeteksi keragaman genetika.

\section{Ucapan Terima Kasih}

Penelitian ini terselenggara atas bantuan dana dari Program Kompetitif Sub Program Domestikasi Flora dan Fauna Tahun 2005 dan 2006. Terima kasih juga kepada Sdr. Agustina, Arief Hidayat dan Hamzah yang telah membantu penelitian ini.

\section{Daftar Pustaka}

Anonimous. 2006. Kalteng Pos Online. http://www. kaltengpos.com. 07/24/2006.

Boer, R. dan Ella, A.B. 2000. Plant Producing Exudates. Plant Resorces of South-East Asia (PROSEA) 18. Backhuys Publishers, Leiden.

Delaporta, S.L., Wood, J. dan Hicks, J.B. 1983. A Plant DNA Minipreparation. Version II. Plant Molecular Biology Reporter, 4: 19-21.

Dunn, G. dan Everitt, B.S. 1982. An Introduction to Mathematical Taxonomy. Cambridge University Press. Cambridge.

Islam, M.A., Kloppstech, K. dan Esch, E. 2005. Population Genetic Diversity of Curcuma zedoaria (Christm.) Roscoe-a Conservation Prioritized Medicinal Plant in Bangladesh. Conservation Genetics, 6: 1027-1033.

Hardiyanto, E.B. dan Na'iem, M. 2001. Present Status of Conservation, Utilization, and Management of Forest Genetic Resources in Indonesia. In: Proceedings of the South East Asian Moving Workshop on Conservation, Management of Forest Genetic Resources. FAO Corporate Document Repository. 
Jones, C.J., Edwards, K,J., Castagiole, S., Winfield, M.O., Sala, F., Van del Wiel, C., Bredemeijer, G., Vosman, B., Matthes, M., Daly, A., Brettsshneider, R., Bettini, P., Buiatti, M., Maestri, E., Malcevschi, A., Marmiroli, N., Aert, R., Volckaert, G., Rueda, J., Linacero, R., Vasquez, A. dan Karp, A. 1997. A Reproducibility Testing of RAPD, AFLP and SSR Markers in Plants by a Network of European Laboratories. Molecular Breeding, 3 (5): 382-390.

Mori, E.S., Kageyama, P.Y., de A Veiga, R.F., Zimback, L. dan Mello Junior, J.R.S. 2004. Genetic Structure of Trichilia pallida Swartz (Meliaceae) Populations by RAPD Markers. Scientia Forestalis, 65: 114-119.

Nei, M. 1972. Genetic Distance Between Populations. American Naturalist, 106: 283-292.

Nei, M. 1973. Analysis of Gene Diversity in Subdivided Populations. Proceedings of National Academy of Science USA, 70: 3321-3323.

Nei, M. 1978. Estimation of Average Heterozygosity and Genetic Distance from a Small Number of Individuals. Genetics, 89: 583-590.

Norwati, M. 2002. Jelutung. In: Krishnapillaly, B. (Eds.). A Manual for Forest Plantation Establishment in Malaysia. Malayan Forest Record No. 45: 165-171.

Page, R.D.M. 1998. TreeView (Win 32). Available at: http://www.taxonomy.zoology.gla.ac.uk/rod/rod .html. 21/07/2008.

Pither, R., Shore, J.S. dan Kellman, M. 2003. Genetic Diversity of the Tropical Tree Terminalia amazonia (Combretaceae) in Naturally Fragmented Populations. Heredity, 91 (3): 3017-313.

Rath, P., Rajaseger, G., Goh, C.J. dan Kumar, P. 1998. Phylogenetic Analysis of Dipterocarps using Random Amplified Polymorphic DNA Markers. Annals of Botany, 82: 61-65.

Rimbawanto, A., Widyatmoko, A.Y.P.B.C. dan Harkingto. 2006. Keragaman Populasi Eusideroxylon zwageri Kalimantan Timur Berdasarkan Penanda RAPD. J. Penelitian Hutan Tanaman, 3 (3): 201-208.

Rohlf, F.J. 1993. NTSYS-pc Numerical Taxonomy and Multivariate Analysis. Version 1.80.Applied Biostatistics Inc.

Runo, M.S., Muluvi, G.M. dan Odee, D.W. 2004. Analysis of Genetic Structure in Melia volkensii (Gurke.) Populations using Random Amplified Polymorphic DNA. African J. of Biotechnology, 3 (8): 421-425.

Shashidhara, G., Hema, M.V., Koshy, B. dan Farooqi, A.A. 2003. Assessment of Genetic Diversity and
Identification of Core Collection in Sandalwood Germplasm using RAPDs. J. of Horticultural Science \& Biotecnology, 78 (4): 528-536.

Siregar, U.J., Sudarmonowati, E. dan Hartati, N.S. 1998. Development od RAPD Protocol for Shorea laevis. Annales Bogorienses, 5 (2): 85-92.

Singh, D.R.P., Singh, R., Malik, K. dan Randhawa, G.J. 2005. Assessment of Genetic Diversity and Genetic Relationship among 29 Populations of Azadirachta indica A. Juss. Using RAPD marker. Genetic Resources and Crop Evolution, 52 (3): 285-292.

Soerianegara, I. dan Lemmnes, R.H.M.J. 1993. Timber Trees: Major Commercial Timbers. Plant Resorces of South-East Asia (PROSEA) 5 (1): 19.

Telles, M.P.C., Coelho, A.S.G., Chaves, L.J., Diniz-Filho, J.A.F. dan D'Ayala Valva, F. 2003. Genetic Diversity and Population Structure of Eugenia dysenterica DC. (Myrtaceae) in Central Brazil: Spatial Analysis and Implications for Conservation and Management. Conservation Genetics 4: 685-695.

Tingey, S.V., Rafalski, J.A. dan Hanafey, M.K. 1994. Genetic Analysis with RAPD Markers: In: Coruzzi, C. and Puidormenech, P. (Eds.). Plant Molecular Biology, 491-498.

Widjaja, E.A. dan Poerba, Y.S. 2004. Pengumpulan Data Plasma Nutfah dan Genetika. In: Rugayah, E.A., Widjaya dan Praptiwi (Eds). Pedoman Pengumpulan Data Keanekaragaman Flora. Pusat Penelitian Biologi-LIPI.

Williams, J.G., Kubelik, A.R., Livak, K.J., Rafalsky, J.A. dan Tingev, S.V. 1990. DNA Plolymorphism Amplified by Arbitrary Primers are Useful as Genetic Markers. Nucleic Acid Research 18 (22): 6531-6535.

Wiriadinata, H. 2001. Tumbuhan. In: Noerdjito, M. and Maryanto, I. (Eds). Jenis-jenis Hayati yang Dilindungi Perundang-undangan Indonesia. Balitbang Zoologi (Museum Zoologicum Bogoriense) Puslitbang Biologi-LIPI \& The Nature Conservancy.

Weeden, N.F., Timmerman, G.M., Hemmat, M., Kneen, B.E. dan Lodhi, M.A. 1992. Inheritance and Reliability of RAPD Markers. Application of RAPD Technology to Plant Breeding. Joint Plant Breeding Symposia Series CSSA/ASHS/AGA. Minneapolis, 1 November 1992.

Yeh, F.C., Yang, R.C. dan Boyle, T. 1999. Popgene Version 1.31. Microsoft Windows-based freeware for Population Genetic Analysis. Available at: http://www.ualberta.ca/ fyeh/ download.htm. 07/14/2008. 